\title{
Nye og gode sykehusnavn
}

\author{
Det kan være mange grunner til at sykehus skifter navn: ny eier, ny organisasjonsstruktur, ny status \\ eller et ønske om en ny start. Et navneskifte er en god anledning til å skape et godt merkevarenavn.
}

Helsereformene i 2001-02 medførte dramatiske endringer i sykehusstrukturen i Norge. Fylkeskommunene var ikke lenger sykehuseiere, og betegnelsene lokalsykehus, fylkessykehus, sentralsykehus og regionsykehus var utdaterte. Mange sykehus måtte skifte navn (1). Noen sykehus benyttet anledningen til å finne et navn som formidlet et viktig budskap, og som posisjonerte sykehuset på en fordelaktig måte.

\section{Universitetssykehuset Nord-Norge} Et av de første sykehusene som endret navn, var Regionsykehuset i Tromsø, forkortet og ofte omtalt som RiTø. Det nye navnet - Universitetssykehuset Nord-Norge
Hvem som sto bak dette stuntet, vites ikke, men fylkestingsrepresentantene falt åpenbart for både oppvisningen og kongens forslag.

Navnet St. Olavs hospital har en sterk historisk og lokal forankring og påminner alle om landsdelens sentrale rolle i norsk historie. Det er kort, lett å si og oppfatte, også for utlendinger. Det kom noen kritiske røster omkring navnets religiøse karakter, men navnet kom fort i bruk og ble raskt akseptert. På brevark og i annonser står Universitetssykehuset $\mathrm{i}$ Trondheim oppført som en forklarende undertittel til navnet St. Olavs hospital. Enkelte forskere legger ofte til University Hospital of Trondheim i adresselisten på sine engelskspråklige,

\section{«Forkortelsen UNN er kort, lett å bruke og gir hyggelige assosiasjoner - hvem vil mislike å bli tatt hånd om av Unn når man blir syk?»}

- får tydelig frem sykehusets status som universitetssykehus, og at sykehuset er hele landsdelens sykehus - ikke bare Tromsøområdets. Forkortelsen UNN er kort, lett å bruke og gir hyggelige assosiasjoner hvem vil mislike å bli tatt hånd om av Unn når man blir syk?

\section{St. Olavs hospital}

I Trondheim ble forkortelsen for Regionsykehuset i Trondheim - RiT - brukt i prosjektnavnet til en helt ny sykehusorganisasjon i helt nye bygninger - RIT2000. Etter hvert som disse planene ble endret og utsatt, ble RIT2000 til både RIT2010 og RIT3000 på folkemunne.

Det nye sykehusnavnet ble St. Olavs hospital, uten at saken visstnok var særlig utredet eller diskutert på forhånd. Etter sigende opptrådte en skuespiller som Olav den hellige under et møte i fylkestinget i SørTrøndelag, der han med stor pondus forlangte at det nye sykehuset måtte bære hans navn (Steinar Westin, personlig meddelelse). vitenskapelige publikasjoner, ev. sløyfer navnet St. Olav's Hospital helt (Geir Jacobsen, personlig meddelelse). Noe nytt navnskifte er likevel neppe aktuelt.

\section{Stavanger universitetssjukehus}

Sentralsjukehuset i Rogaland var ikke et universitetssykehus i den forstand at det var tilknyttet et universitet i samme by. Men forsknings- og undervisningsaktiviteten ved sykehuset økte gradvis utover i 1990-årene. I 2004 hadde rundt 30 av sykehusets overleger bistilling som professor ved Det medisinske fakultet ved Universitetet i Bergen. Sykehuset var «som et universitetssykehus», som det het i direktørenes saksfremlegg for styret om nytt navn (2). Derfor skiftet sykehuset navn til Stavanger universitetssjukehus fra 1.2. 2005.

Dette navnet reflekterer Stavanger-områdets økte betydning og selvbevissthet og sykehusets ambisjoner om å utvikle universitetsfunksjonene videre - kanskje til et eget medisinsk fakultet?

\section{Akershus universitetssykehus}

Sentralsykehuset i Akershus har drevet klinisk undervisning av medisinske studenter i mer enn 40 år, altså mye lenger enn sykehuset i Stavanger. Med helsereformene og byggingen av et helt nytt sykehusbygg på Lørenskog var det ønskelig at sykehuset fikk et helt nytt navn. Forkortelsen SiA var hendig og mye brukt - ville man klare å finne en like god forkortelse?

Løsningen ble at sykehuset skiftet navn til Akershus universitetssykehus med kortversjonen Ahus til bruk i det daglige. Navnet Ahus ble raskt akseptert og brukes mye av både presse, folk flest og helsepersonell.

\section{Oslo universitetssykehus?}

I Oslo ble Rikshospitalet, Radiumhospitalet, Ullevål universitetssykehus og Aker universitetssykehus slått sammen til ett stort sykehus fra 1.1.2009. Det ble tidlig bestemt at navnet på det nye sykehuset skulle være Oslo universitetssykehus forkortet OUS. Det er usikkert om folk, pasienter og ansatte vil bruke navnet Oslo universitetssykehus eller forkortelsen OUS fremfor sterke merkevarenavn som Rikshospitalet, Radiumhospitalet, Ullevål sykehus og Aker sykehus. Men det er en annen historie $(1,3)$.

\section{Petter Gjersvik}

petjense@online.no

Observatorie terrasse $7 \mathrm{C}$

0270 Oslo

Oppgitte interessekonflikter: Forfatteren er førsteamanuensis ved Oslo universitetssykehus, Rikshospitalet, og medisinsk redaktør i Tidsskriftet.

\footnotetext{
Litteratur

1. Gjersvik P. Ett sykehus - flere merkevarenavn. Tidsskr Nor Legeforen 2010; 130: 1905

2. Helse Stavanger. Mulig navneskifte for SIR www.helse-stavanger.no (28.10.2010).

3. Hem E. Vil «Radiumhospitalet» bestå? Tidsskr Nor Legeforen 2010; 130: 1740.
}

Mottatt 26.9. 2010 og godkjent 27.10. 2010. Medisinsk redaktør Raida Ødegaard. 